\title{
Odontarrhena stridii (Brassicaceae), a new Nickel-hyperaccumulating species from mainland Greece
}

\author{
Lorenzo Cecchi ${ }^{1} \cdot$ Stanislav Španiel ${ }^{2,3} \cdot$ Elisabetta Bianchi ${ }^{4} \cdot$ Andrea Coppi $^{4} \cdot$ Cristina Gonnelli $^{4} \cdot$ Federico Selvi $^{5}$ (I)
}

Received: 26 November 2019/ Accepted: 27 April 2020

(c) Springer-Verlag GmbH Austria, part of Springer Nature 2020

\begin{abstract}
Odontarrhena is a taxonomically difficult genus of the tribe Alysseae, including a number of critical species complexes in the Balkan Peninsula. One of these is $O$. baldaccii, which was previously included in the inconsistent taxon Alyssum fallacinum but recently shown to be distinct from it. In this paper, we analyzed the still uncertain taxonomic circumscription of $O$. baldaccii by a comparative analysis of the population from the type locality in Crete and other populations from mainland Greece, which were previously attributed to A. fallacinum or dubitatively included in $O$. baldaccii s.l. The results supported the separation of these mainland populations in a new distinct species, here described as Odontarrhena stridii, sp. nov. Plant habit, leaf shape and size and silicle shape were the major distinguishing morphological characters. Molecular data also suggested divergence between the two groups of populations, while supporting their phylogenetic affinity. The two species are diploid schizo-endemics with $2 n=16$, allopatric distribution and specialization for serpentine soils. Shoot Ni concentrations well above $1000 \mu \mathrm{g} \mathrm{g}^{-1}$ dry weight were confirmed for the Cretan population of $O$. baldaccii and found for the first time in two populations of $O$. stridii, which is therefore a new hyperaccumulating species of the Balkan Mediterranean flora. An updated key to the Greek Odontarrhena taxa is provided.
\end{abstract}

Keywords Alyssum $\cdot$ Balkan flora $\cdot$ Cruciferae $\cdot$ Nickel-hyperaccumulators $\cdot$ Serpentine endemics

Handling Editor: Ivana Rešetnik.

Contribution to "Plants of the Balkan Peninsula in Space and Time".

Electronic supplementary material The online version of this article (https://doi.org/10.1007/s00606-020-01687-3) contains supplementary material, which is available to authorized users.

Federico Selvi

federico.selvi@unifi.it

$1 \quad$ Natural History Museum, Botanical Collections "Filippo Parlatore", University of Firenze, Via G. La Pira 4, 50121 Florence, Italy

2 Institute of Botany, Plant Science and Biodiversity Centre, Slovak Academy of Sciences, Dúbravská cesta 9, 84523 Bratislava, Slovakia

3 Department of Botany, Faculty of Science, Charles University in Prague, Benátská 2, 12801 Prague, Czechia

4 Department of Biology, University of Firenze, Via P.A. Micheli 1, 50121 Florence, Italy

5 Department of Agriculture, Food, Environment and Forestry, Laboratories of Botany, University of Firenze, P.le delle Cascine 28, 50144 Florence, Italy

\section{Introduction}

Though established before the mid of the nineteenth century (Ledebour 1830), the genus Odontarrhena has almost invariably been considered as a section of the genus Alyssum L. [Alyssum sect. Odontarrhena (C.A.Mey ex Ledeb.) W.D.J.Koch] due to a general external resemblance of the taxa in these two groups. However, morphological and molecular evidence clearly showed that Alyssum and Odontarrhena are monophyletic clades within the tribe Alysseae, deserving separate generic status (Warwick et al. 2008; Cecchi et al. 2010; Rešetnik et al. 2013; Li et al. 2015). According to the AlyBase database (Španiel et al. 2015), Odontarrhena includes 87 species mainly distributed in the Euro-Mediterranean and Irano-Turanian regions. The Balkan Peninsula is a major diversity center, hosting numerous endemics mainly restricted to serpentine soils (Stefanovic et al. 2003). Nearly all serpentinophytic taxa in this genus are able to accumulate nickel in concentrations well above the accepted hyperaccumulation threshold of $1000 \mu \mathrm{g} \mathrm{g}^{-1}$ of dry weight in their leaves (Morrison et al. 1980; Tumi et al. 2012; Kidd et al. 2018), a rare physiological feature that 
is not present in Alyssum. This makes some Odontarrhena species promising plants for biotechnological applications such as phytoremediation and agromining (Kidd et al. 2018).

Despite the monographic works by Nyárády (1928, 1929a, b, 1930, 1932, 1939, 1949), the genus remains taxonomically critical because of the lack of modern revisions addressing a number of still unresolved questions concerning the identity and correct name for several taxa.

This is the case of $O$. baldaccii (Vierh. ex Nyár.) Španiel, a plant collected by Antonio Baldacci on 8 June 1899 on a small ultramafic outcrop on the north-eastern side of Mt. Psiloritis in Crete and described by Nyárády (1928) as Alyssum baldaccii Vierh. ex Nyár. Considered by many authors as a synonym of the earlier A. fallacinum Hausskn. $[\equiv O$. fallacina (Hausskn.) Španiel, Al-Shehbaz, D.A.German \& Marhold] (Ball and Dudley 1993; Jalas and Suominen 1996; Marhold 2011; Španiel et al. 2015), it was instead regarded as a good species by Hartvig (2002) and Fielding and Turland (2005), and recently confirmed to be distinct from $O$. fallacina based on the study of type material of both taxa (Španiel 2019). Actually, O. baldaccii is thought to be the only obligate serpentine plant on Crete (Fielding and Turland 2005).

However, the limits and circumscription of this taxon are still uncertain. Although it was originally regarded as a strict Cretan endemic by Nyárády $(1928,1949)$ and Vierhapper and Rechinger (1935), in Flora Hellenica (Hartvig 2002) and Flora of Greece Web (Dimopoulos et al. 2018), it was considered also inclusive of similar plants from continental Greece previously referred to $O$. fallacina. In more recent times, however, Strid (2016) expressed doubts that these mainland populations are conspecific with the Cretan plant, in line with the original narrow concept of $O$. baldaccii held by Nyárády $(1928,1949)$ and Vierhapper and Rechinger (1935).

During field trips across mainland Greece and Crete, we had the opportunity to observe native populations and collect material for a more in-depth investigation of this taxon. This study highlighted morphological and molecular divergence between the two allopatric groups of populations, supporting the original narrow circumscription of $O$. baldaccii. Accordingly, the continental populations are referred to a new species which is described and illustrated here. By determining nickel levels in plant and soil samples from the two parts of the distribution range, we found that both are able to accumulate this metal well above the hyperaccumulation threshold. In addition, we analyzed nickel concentration in populations of two other species involved in the taxonomic issue of $O$. baldaccii, namely $O$. heldreichii (Hausskn.) Španiel, Al-Shehbaz, D.A.German \& Marhold and $O$. chalcidica (Janka) Španiel, Al-Shehbaz, D.A.German \& Marhold, both from north Pindos near the type locality of A. fallacinum. This paper can therefore provide updated information to the Global Hyperaccumulator Database (Reeves et al. 2018).

\section{Materials and methods}

\section{Plant material and morphology}

In summer and autumn of the years 2008, 2017, 2018 and 2019 , we could observe and sample native populations of $O$. baldaccii s.1., O. heldreichii, "O. fallacina" and other related taxa, in their type localities in Crete and mainland Greece. Voucher specimens are deposited in FI. In addition, we examined original materials and types of all taxa involved, as well as additional collections obtained from B, C, FI, G, W and WU. Morphology was examined with a standard stereomicroscope and a scanning electron microscope (FEI ESEM-QUANTA 200), for a better observation of trichomes on leaf and fruits samples.

To summarize variation in macro-morphology, ten fruiting specimens of the population from Crete and 15 from three populations from mainland Greece (Thessaly: Kedhros, Mt. Kallidromo and monastery of Kato Xenia near Almirós) were scored for 11 major quantitative characters concerning the size of the plant, basal and cauline leaves (five per specimen), fruit and seed (30 silicles from at least five plants for each population). The resulting matrix (Online Resource 1) was subject to Principal Component Analysis with PAST version 3.26 (Hammer et al. 2001).

\section{Karyology}

Chromosome analyses were performed on mitotic metaphase plates of cells from meristematic tissue of root tips of germinated seeds. Tips were pretreated with $0.002 \mathrm{M} 8$-hydroxyquinoline for $2.5 \mathrm{~h}$ at room temperature and then fixed overnight in ethanol/glacial acetic acid (3:1). The meristematic tissue was then rinsed in distilled water, hydrolyzed in $1 \mathrm{M} \mathrm{HCl}$ at $60{ }^{\circ} \mathrm{C}$ for 6-7 min and stained in lacto-propionic orcein overnight. The meristems were dissected and squashed in a drop of 45\% acetic acid (Dyer 1979; Selvi and Sutorý 2012). Metaphase plates were examined with a Zeiss Axioscop light microscope under oil immersion $(\times 100)$.

\section{Nickel concentration in soil and plant samples}

Five plants of $O$. baldaccii s.s. were randomly chosen and collected in type locality at the northern foot of Mt. Psiloritis in Crete (close to the village of Gonies), five for each of two populations of $O$. baldaccii s.l. from mainland Greece (Kedhros and Kato Xenia), one typical population of O. heldreichii from Katara Pass and one of O. chalcidica from the upper Penei valley close to the type locality of $O$. fallacina. 
Geographic details of these populations are given in Appendix. At each locality (except for the one of $O$. chalcidica), we also collected five bulk soil samples of ca. $40 \mathrm{~g}$ at $1-10 \mathrm{~cm}$ depth, which were then pooled together to obtain a single bulk soil sample of ca. $200 \mathrm{~g}$.

Preparation of the soil and plant material followed Selvi et al. (2017) and Bettarini et al. (2019).

Soil was air-dried, sieved with a $2-\mathrm{mm}$ mesh stainless steel sieve and fully dried in oven at $50{ }^{\circ} \mathrm{C}$ for 7 days. From each bulk sample, five subsamples of about $0.5 \mathrm{~g}$ were digested using $10 \mathrm{~mL}$ of $69 \% \mathrm{HNO}_{3}$ in a microwave system (Mars 6, CEM). Nickel concentration in the digests was determined by flame atomic absorption spectroscopy (AAS) using PinAAcle 500 (Perkin Elmer). Dried plant samples were carefully washed with deionized water, blotted dry with filter paper, oven-dried at $50{ }^{\circ} \mathrm{C}$ for $48 \mathrm{~h}$ and grounded, separately for shoots and roots (only shoots for O. chalcidica). Samples were then mineralized by a microwave-assisted digestion with concentrated $\mathrm{HNO}_{3}$; each of the five samples was analytically replicated three times, to obtain a mean value of $\mathrm{Ni}$ concentration by means of AAS.

\section{Molecular analyses}

The relationships between the Cretan populations of $O$. baldaccii, those from mainland Greece currently referred to this species, $O$. heldreichii, O. chalcidica and other taxa from adjacent countries were investigated using nrITS. This marker has been widely used in previous analyses of Alysseae and Alyssum s.l. for its useful phylogenetic signal (Warwick et al. 2008; Cecchi et al. 2010, 2013; Rešetnik et al. 2013; Li et al. 2015; Salmerón-Sánchez et al. 2018; Melichárková et al. 2019), while cpDNA sequences have usually only limited value for species delimitation and phylogenetic inference, as in the case of the related genus Alyssum (Zozomová-Lihová et al. 2014; Španiel et al. 2017). All sequences were retrieved from GenBank except for typical $O$. baldaccii from Crete, not previously investigated. Genomic DNA of the Cretan plants was extracted from silica-gel dried samples of leaf tissue using a modified $2 \times$ CTAB protocol (Doyle and Doyle 1990) and quantified after agarose gel electrophoresis. Amplification and sequencing of the nrITS region were performed as described in Coppi et al. (2018).

A set of 33 accessions of Odontarrhena, of which one resulting from this study, was used for the phylogenetic analysis, plus three of Alyssum as outgroup representatives (Online Resource 2). Alignment was performed with MAFFT v. 7.0 (online version; Katoh and Standle 2013) using the Q-INS-1 strategy, which is a slow, accurate, iterative refinement method recommended for small-scale alignments. Gaps were coded as separate characters according to Simmons and Ochoterena (2000) using FastGap v.1.2
(Borchsenius 2009) and appended at the end of the data sets. Alignment is provided as Online Resource 4.

Trees were obtained using Bayesian inference of phylogeny as implemented in MrBayes 3.1.2 (Ronquist and Huelsenbeck 2003); based on FindModel (Posada and Crandall 1998), the best substitution model was GTR $+\Gamma$ with gamma-distributed rate variation across sites. The analysis was performed using four incrementally heated Markov chains (one cold, three heated) simultaneously started from random trees, and run for one million cycles sampling a tree every ten generations. The stationary phase was reached when the average standard deviation of split frequencies reached 0.01 . Trees that preceded the stabilization of the likelihood value (the burn-in) were discarded, and the remaining trees were used to calculate a majority-rule consensus phylogram.

\section{Results}

\section{Morphology}

Principal Component Analysis of the character values matrix explained $91.3 \%$ of the total variation (PC1: $77.7 \%$; $\mathrm{PC} 2$ : 13.6\%). The resulting scatterplot (Fig. 1) showed continuous variation between the 25 samples, but those from Crete were mostly grouped on the negative part of PC1, while the continental ones were mainly lying on the positive part. The most important variables in producing this pattern were plant height and size of the leaves, both higher in the Cretan plants. Their basal shoots were provided with numerous oblanceolate-spathulate leaves of 9-18×2-4 mm, with long attenuate base (Figs. 2e, 3b), while in the continental plants these leaves were smaller $(3-8 \times 0.8-1.8 \mathrm{~mm})$, narrowly oblanceolate to almost linear, with shortly attenuate base (Figs. 2b, 3c). Similarly, leaves on fertile stems were smaller in the continental plants (maximum size $15 \times 3 \mathrm{~mm}$ vs. $24 \times 4.5 \mathrm{~mm}$ in samples from Crete). In addition, the Cretan plants were on average wider and more richly branched from base, with more numerous sterile shoots and a more fruticose habit (Figs. 2a, d, 3a, b).

The typical sublepidote stellate trichomes were very similar in the two groups of populations, as well as in $O$. heldreichii and $O$. chalcidica from north Pindus (Fig. 4a-d). However, the mean trichome diameter was slightly higher in plants from Crete than in the continental ones $(0.3-0.5 \mathrm{~mm}$ vs. $0.2-0.3 \mathrm{~mm}$ ). In the Cretan specimens, trichome rays were also forked closer to the base, hence, with thinner and more numerous branches (24-28 vs. 20-24; Fig. 4c). In both groups of accessions, there were granular thickenings on the whole trichome surface, which were especially dense in the continental plants (Fig. 4a); such thickenings appeared much sparser on the trichomes of $O$. heldreichii (Fig. 4b). 


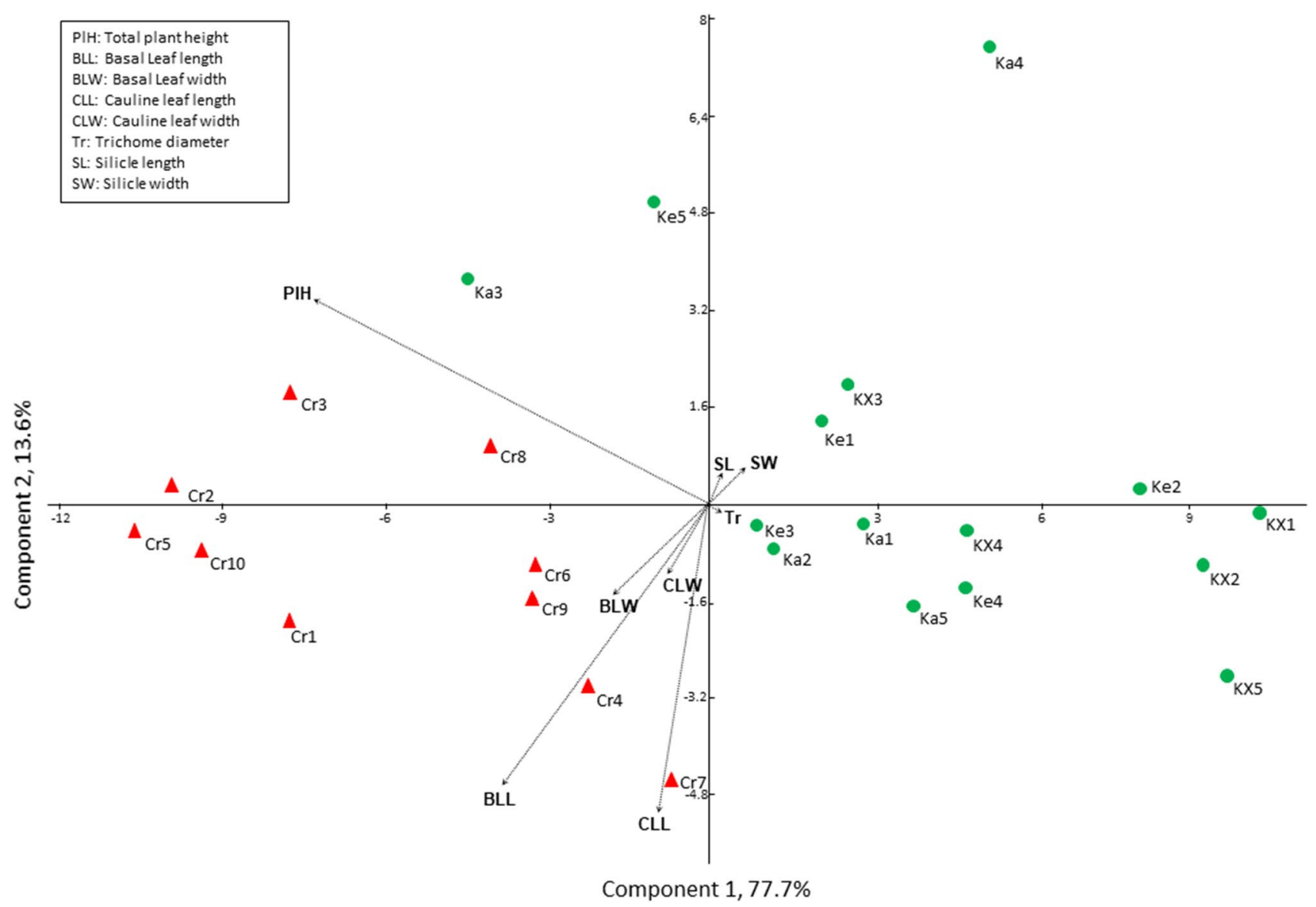

Fig. 1 PCA scattergram showing morphometric relationships between plants of Odontarrhena baldaccii s.s. from Crete $(\mathrm{Cr}$; red triangles) and $O$. stridii $(=O$. baldaccii s.l. from continental Greece)

Fruit size was relatively uniform in the Cretan plants but somewhat variable in the continental accessions, both within and between populations (Fig. 5a, b). Though most of these accessions showed slightly larger silicles, there were specimens with smaller fruits like in plants from Crete. Fruit shape, however, was slightly but consistently different in the two groups of accessions. In fact, the silicles of the continental plants were usually slightly widened in the upper half and elliptic-obovate in shape (mean length/ width ratio $=1.33 \pm 0.13$; Figs. $2 \mathrm{c}, 3 \mathrm{e}, 5 \mathrm{a}$ ), while those from Crete were more elliptic, usually not or less distinctly widened above (mean $L / W$ ratio $=1.62 \pm 0.19$; Figs. $2 \mathrm{~g}, 3 \mathrm{f}, 5 \mathrm{~b}$ ). In addition, silicles of the continental plants were usually slightly asymmetrical and S-shaped in cross section, unlike those in the Cretan accessions.

Trichomes on silicle valves were very similar in the two groups of accessions, though density was often slightly higher in the Cretan plants. In both accessions, mature fruits were inflated on one side because of the seed. A very narrow
(Ka: Mt. Kallidromo, Ke: Kedhros, KX: Kato Xenia; green dots), based on 11 quantitative characters (Online Resource 1). Vectors relative to style length, seed length and width of seed wing are not shown

wing $(<0.15 \mathrm{~mm})$ was usually present around at least part of the seed, in both groups of accessions.

\section{Karyology}

Our chromosome observations (Online Resource 3) confirmed that $O$. baldaccii from Crete is diploid with $2 n=2 x=16$, as reported by De Montmollin (1984, sub Alyssum fallacinum Hausskn.). The same number was found in plants from Kedhros, which were not apparently investigated before, and in $O$. heldreichii from north Pindus, in line with a previous report by Contandriopoulos (1970). On the contrary, $O$. chalcidica from north Pindus near Malakasi was tetraploid with $2 n=4 x=32$, confirming recent observations on different populations of this taxon from Albania (Cecchi et al. 2018) but not others of $2 n=16$ referable to the same taxon from northern Greece (Strid 1983, sub Alyssum chlorocarpum Hausskn.). In all plates examined, chromosome were small-sized (ca. 1.9-3.1 $\mu \mathrm{m}$ ) and mainly meta- or 
Fig. 2 Odontarrhena stridii $(=O$. baldaccii s.1.) from

Mt. Kallidromo and Sterea

Ellas, mainland Greece (a-c) and $O$. baldaccii s.s. from Mt. Psiloritis, Crete (d-g), showing, respectively: habit (a, d); variability of the leaves of the basal sterile shoots (b, e; in $\mathbf{b}$, the small leaf to the right is seen from below; the other two are seen from above; in $\mathbf{e}$, the right half of the blade shows the abaxial side with denser trichomes); open silicle with seed inside $(\mathbf{c}, \mathbf{g})$; petal (f; only O. baldaccii s.s.). Scale bars: a, $\mathbf{d}=50 \mathrm{~mm} ; \mathbf{b}, \mathbf{e}=10 \mathrm{~mm} ; \mathbf{c}, \mathbf{g}$, $\mathbf{f}=5 \mathrm{~mm}$. Original drawing by L. Cecchi

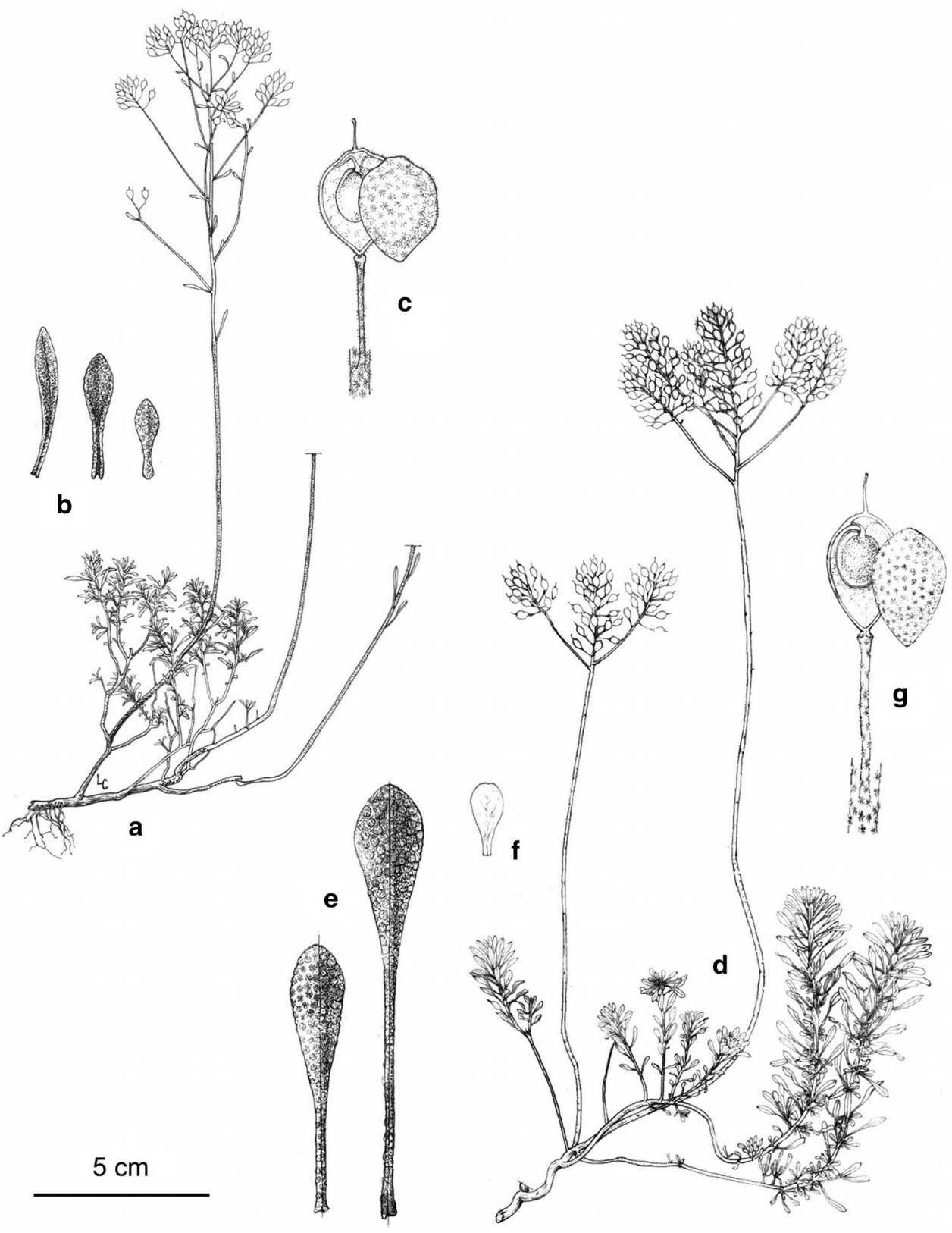

submetacentrics, so that karyotype formulas could not be safely determined.

\section{Nickel concentration}

Mean nickel concentrations in soils of all examined accessions ranged between $1960 \mu \mathrm{g} \mathrm{g}^{-1}$ in the site of Kedhros and $2715 \mu \mathrm{g} \mathrm{g}^{-1}$ in that of Mt. Psiloritis in Crete (Table 1). Such high levels were in line with the ultramafic nature of these sites. Shoot Ni concentrations in the two continental accessions of $O$. baldaccii s.l. were variable and substantially higher in the samples from Kedhros; the latter also had the highest bioaccumulation factor, resulting from the shoot/soil concentration ratio. Typical $O$. baldaccii from Crete showed an intermediate shoot $\mathrm{Ni}$ concentration and the lowest shoot/root ratio. Finally, plants of $O$. chalcidica from near Malakasi in the upper Penei valley had a mean Ni concentration of $12,778 \mu \mathrm{g} \mathrm{g}^{-1}$ of shoot dry weight.

\section{Molecular data}

The aligned ITS matrix was $629 \mathrm{bp}$ long, including coded gap positions (22 pos.); it included 142 variable sites, of which only 97 (15.4\%) were phylogenetically informative. Such a low rate of variation was not unexpected and produced poorly resolved trees. The 50 majority-rule consensus 
Fig. 3 Field photos of Odontarrhena stridii $(=O$. baldaccii s.1.) from mainland Greece, Kedhros (a, c, e) and O. baldaccii s.s. from Crete $(\mathbf{b}, \mathbf{d}, \mathbf{f})$
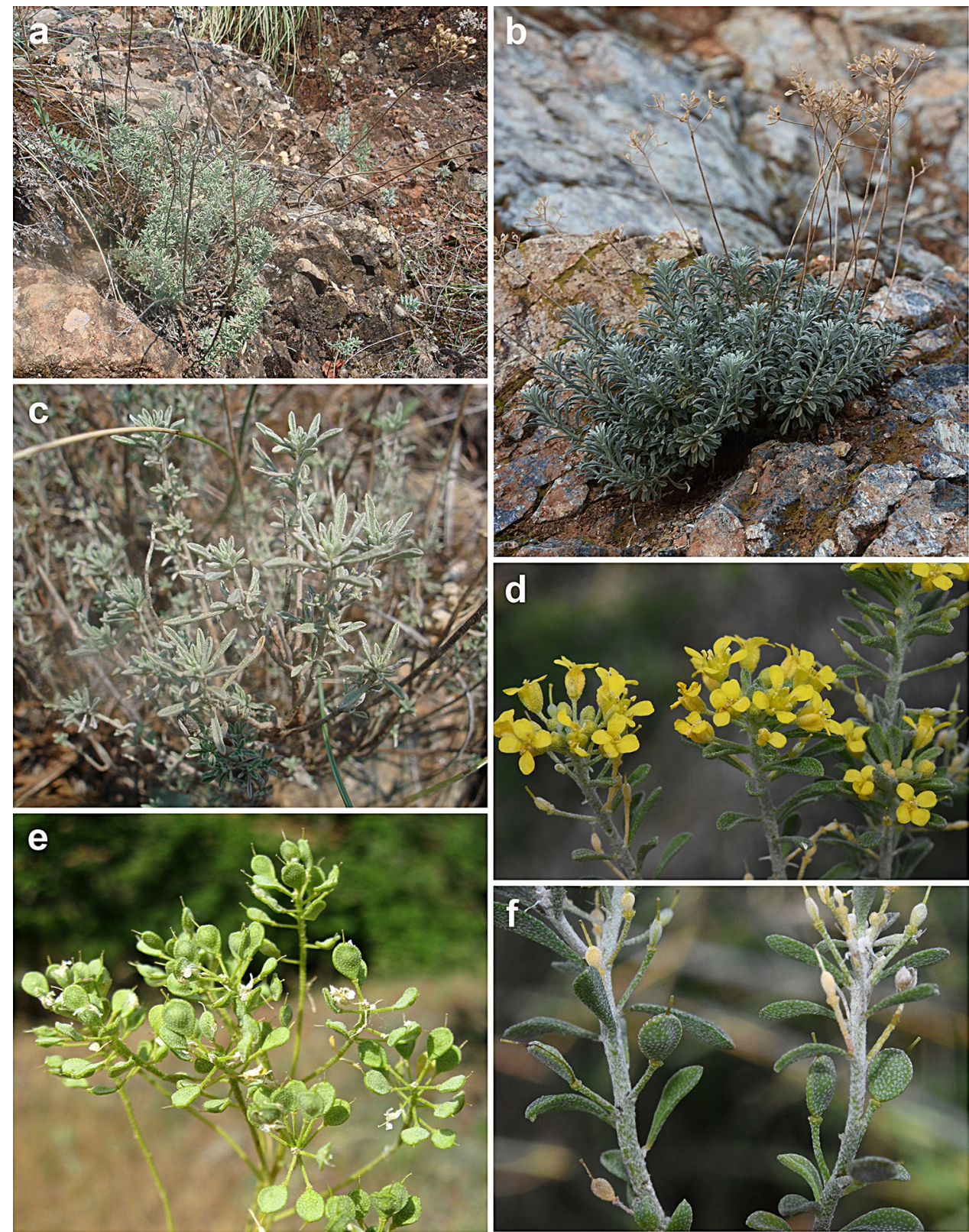

phylogram from Bayesian analysis (Fig. 6), however, supported the monophyly of Odontarrhena (1.00 PP) and retrieved the three accessions of $O$. baldaccii s.l. as separate from the remainder of the ingroup, though with weak support (0.69). The accession from Crete did not cluster with the two continental ones (Kedhros and Mt. Kallidromo), but was external and sister to them and the other accessions, though without strong support $(0.69 \mathrm{PP})$. The sequence of the Cretan plant differed from the two continental ones in 9 single-nucleotide polymorphisms (SNPs), mainly in the ITS2 region. These two accessions appeared in turn sister to the rest of the ingroup, which remained largely unresolved.

\section{Discussion}

Odontarrhena is a taxonomically difficult genus, represented in the Balkan flora by critical species complexes such as $O$. muralis s.l., O. sibirica s.l. and $O$. baldaccii s.l. (Hartvig 2002; Strid 2016; Cecchi et al. 2018). Here, we provide a contribution to the systematics of the latter species, which was recently typified by Španiel (2019) and clearly distinguished from the inconsistent taxon $O$. fallacina, currently the synonym of $O$. heldreichii, into which it was previously included by most authors. 
Fig. 4 SEM micrographs of trichomes on the lower leaf surface of Odontarrhena stridii $(=O$. baldaccii s.1.) from Kedhros, Thessaly (a), $O$. heldreichii from Katara Pass, north Pindus (b), O. baldaccii s.s. from Mt. Psiloritis in Crete (c) and $O$. chalcidica from Malakasi, north Pindus (d)
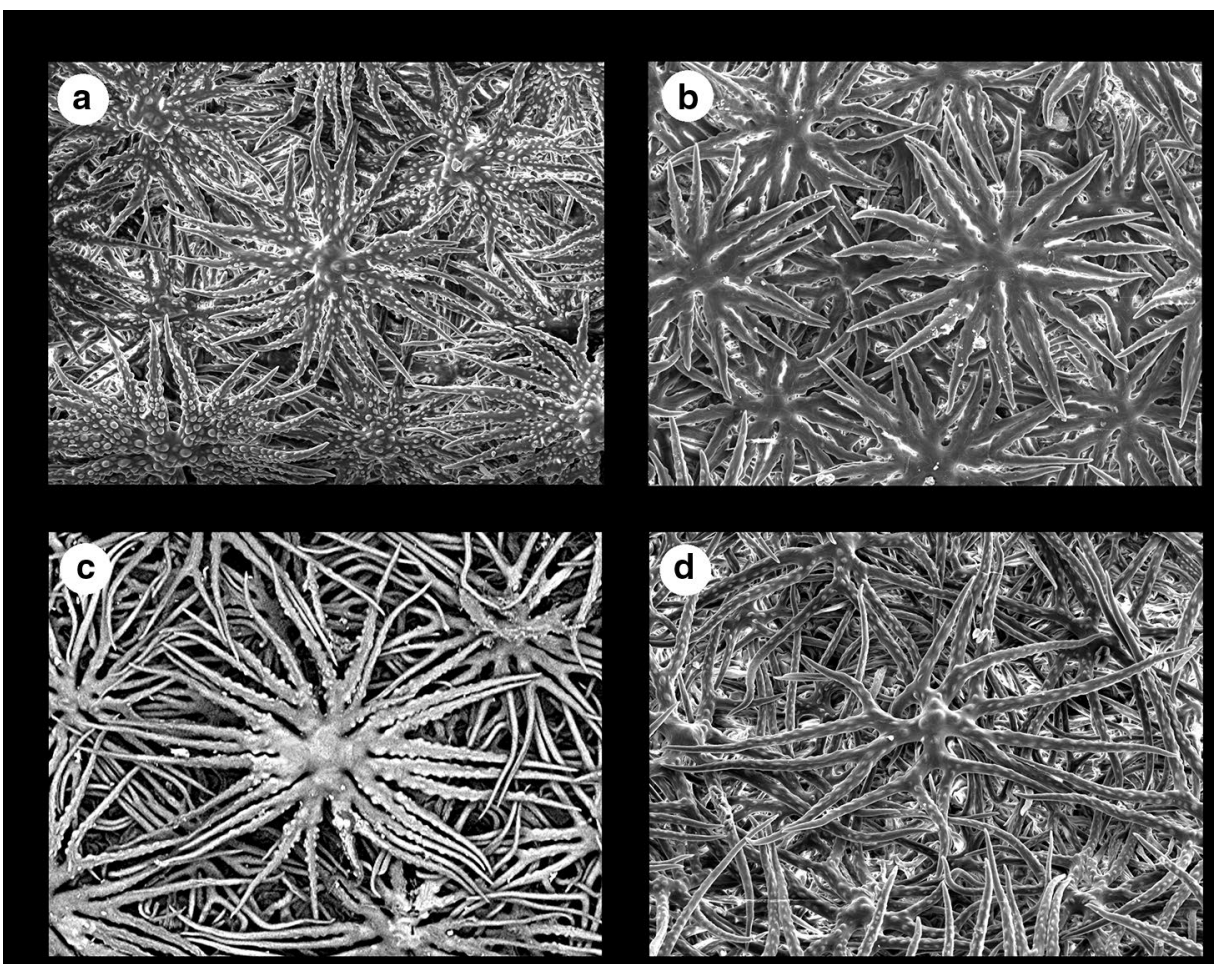

$\vdash^{100}$

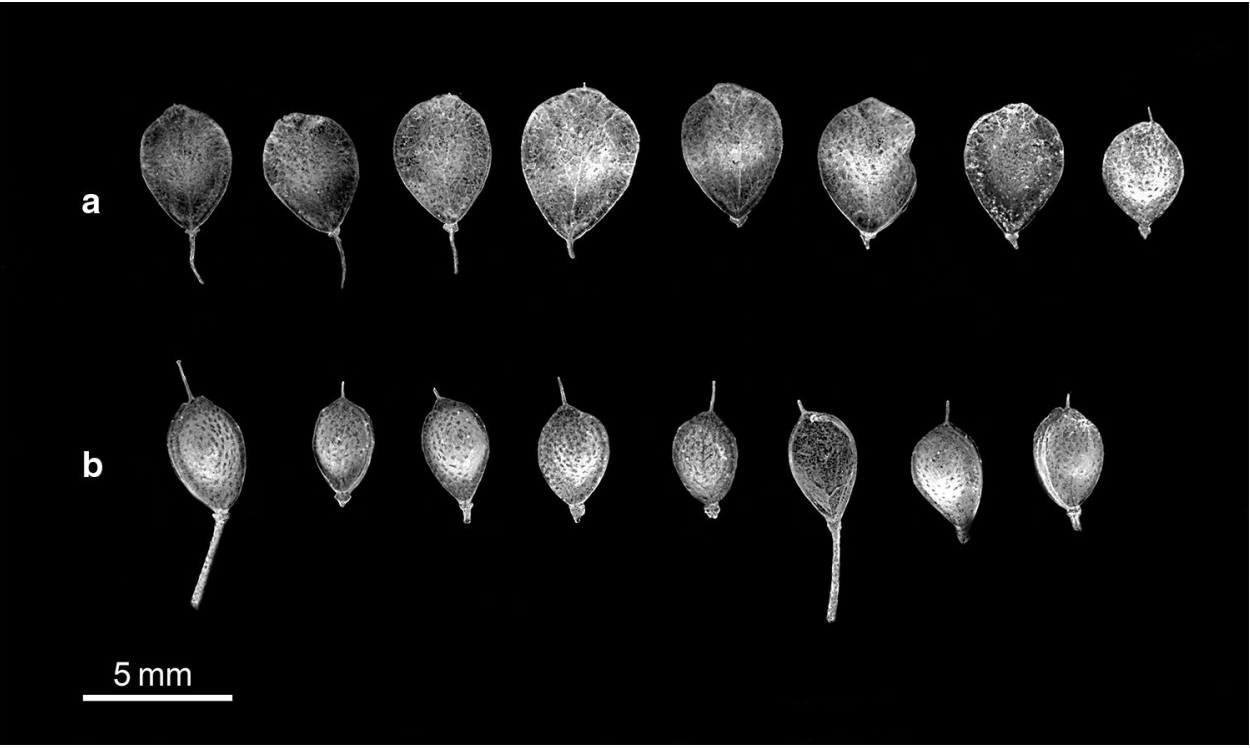

Fig. 5 Mature silicles of Odontarrhena stridii $(=O$. baldaccii s.1.) from Kedhros, Thessaly (a) and $O$. baldaccii s.s. from Crete (b)
According to Strid (2016), O. baldaccii is most likely a Cretan endemic, locally abundant at the north foothills of Mt. Psiloritis in north Crete; the similar plants from mountains in central Greece, often referred to as A. fallacinum, are widely allopatric and not conspecific to it, as originally stated by the authors of the species (Nyárády 1928, 1949; Vierhapper and Rechinger 1935). Our results support this view, by showing a moderate but consistent differentiation between the insular and the mainland populations in morphological and molecular characters. Accordingly, the mainland populations are described here as a new species $O$. stridii (see Taxonomic treatment below). Divergence between them is the likely result of long genetic isolation associated with the wide geographic distance between Crete and the closest populations in continental Greece (ca. $500 \mathrm{~km}$ ). Isolation of $O$. baldaccii is further increased by its strict localization between ca. 500 and $600 \mathrm{~m}$ a.s.1. on the virtually unique Cretan ultramafic outcrop on the 
Table 1 Nickel concentration in soil, root and shoot samples (mean $\mu \mathrm{g} / \mathrm{g}$, values are means of five samples \pm standard error), bioaccumulation factor $(B F=$ shoot/soil ratio) and shoot/root ratio $(S / R)$ in
Odontarrhena baldaccii s.s. from Crete, two accessions $O$. stridii $(=O$. baldaccii s.l. $)$ from mainland Greece, one of $O$. heldreichii and one of $O$. chalcidica

\begin{tabular}{|c|c|c|c|c|c|}
\hline & Soil & Roots & Shoots & $\mathrm{BF}$ & $\mathrm{S} / \mathrm{R}$ \\
\hline O. baldaccii s.s., Crete & $2715 \pm 48$ & $1110 \pm 202$ & $13,150 \pm 2237$ & 4.8 & 12.6 \\
\hline O. stridii, Kedhros & $1960 \pm 40$ & $1145 \pm 245$ & $16,380 \pm 2540$ & 8.3 & 15.7 \\
\hline O. stridii, Kato Xenia & $2409 \pm 30$ & $760 \pm 71$ & $9925 \pm 506$ & 4.1 & 13.4 \\
\hline O. heldreichii, Katara Pass & $1876 \pm 62$ & $320 \pm 61$ & $6650 \pm 1626$ & 3.5 & 20.2 \\
\hline O. chalcidica, Malakasi $\mathrm{i}^{\mathrm{a}}$ & - & - & $12,780 \pm 1870$ & - & - \\
\hline
\end{tabular}

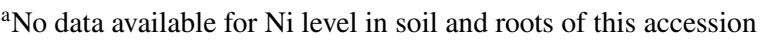

north-eastern slopes of Mt. Psiloritis. This small outcrop is actually a tiny ecological island on a real island, making $O$. baldaccii a very rare and local endemic to be considered for inclusion in the Red Data Book of Greek plants (Phitos et al. 2009). Interestingly, this species does not have any direct affinity to O. fragillima (Bald.) Španiel, Al-Shehbaz, D.A.German \& Marhold, the other Cretan endemic of this genus which is restricted to the subalpine belt of Lefka Ori, on limestone (Hartvig 2002; Strid 2016). Hence, O. baldaccii belongs to the group of obligate serpentine endemics of the Aegean islands such as O. euboea (Rech. fil.) in Evia, O. troodii (Boiss.) Španiel, Al-Shehbaz, D.A.German \& Marhold and $O$. akamasica (B.L. Burtt) Španiel, Al-Shehbaz, D.A.German \& Marhold on Cyprus and O. lesbiaca (Candargy) Španiel, Al-Shehbaz, D.A.German \& Marhold on Lesvos.

Molecular and karyological data are in line with morphology in showing that $O$. baldaccii and $O$. stridii are related to each other and represent two allopatric vicariant schizoendemics (sensu Favarger and Contandriopoulos 1961) with diploid chromosome complement. They probably originated from the same ancestral gene pool and reached their present distribution following range fragmentation or migration events. It is known that land bridges between Crete and the mainland occurred during the Messinian salinity crisis (5.2-1.64 m.y.a.), which allowed flora and fauna to migrate under a hot, dry climate (Fielding and Turland 2005). Long-distance dispersal from the mainland populations to Crete (or vice versa) may also have occurred in later times, though this seems less likely because fruits and seeds have no evident traits for transport by wind or birds. Despite their parapatric distribution in central and northwest Greece and similar chromosome complement, there is no molecular evidence suggesting direct affinity between $O$. stridii and $O$. heldreichii. The latter is usually found at higher altitude (500-2200 $\mathrm{m}$ a.s.1.) and is morphologically well characterized by the indehiscent silicles with thin and distinctly undulate margin, usually pendent on a delicate, flexuous pedicel. In addition, the seeds of $O$. heldreichii are more distinctly winged (wing 0.5-1 mm wide).
In $O$. baldaccii, $O$. stridii and $O$. heldreichii, specialization for serpentine soils is associated with the ability to accumulate Nickel in shoots to concentrations well above $1000 \mu \mathrm{g} \mathrm{g}^{-1}$ of dry weight. This is the first report for continental populations of the $O$. baldaccii complex from the ultramafics of the mainland, which allows to classify $O$. stridii as a new hyperaccumulator species with up to $16,380 \mu \mathrm{g} \mathrm{g}^{-1}$ of $\mathrm{Ni}$ dry weight. Concerning genuine $O$. baldaccii from Crete, our results confirm previous data of $1429-17,670 \mu \mathrm{g} \mathrm{g}^{-1}$ of dry weight (mean 7300; Global Hyperaccumulator Database). The population of $O$. chalcidica from the upper Penei valley in north Pindus was also investigated here for the first time and is confirmed to have high shoot Ni concentrations, in the range of those recently analyzed from Albania (Bettarini et al. 2019). Concerning $O$. heldreichii, our analysis of the population from Katara Pass confirm high $\mathrm{Ni}$ values that are in the (broad) range reported in the literature (1440-32,040 $\mu_{\mathrm{g} \mathrm{g}}{ }^{-1}$, median 8210; Brooks and Radford 1978; Bani et al. 2009).

Therefore, this study brings to 15 the number of species in this genus native to Greece (based on Hartvig 2002; Strid 2016), 11 of which are obligate or facultative serpentinophytes and mostly Ni-hyperaccumulators. A key to these species is provided below.

\section{Taxonomic treatment}

The correlation between the morphological and molecular data described above, coupled with the widely allopatric distribution, shows substantial divergence between the insular and the continental populations of $O$. baldaccii s.l. and supports its splitting in two separate species. Accordingly, the populations from mainland Greece previously referred to this taxon, or to $O$. fallacina (the synonym of $O$. heldreichii, see Španiel 2019), are described as a new species.

Odontarrhena stridii L.Cecchi, Španiel \& Selvi, sp. nov. HOLOTYPE: "Grecia, Sterea Ellas, Fthiotida, versante sudest del Mt. Kallidromon, rocce serpentinose sulla strada tra 


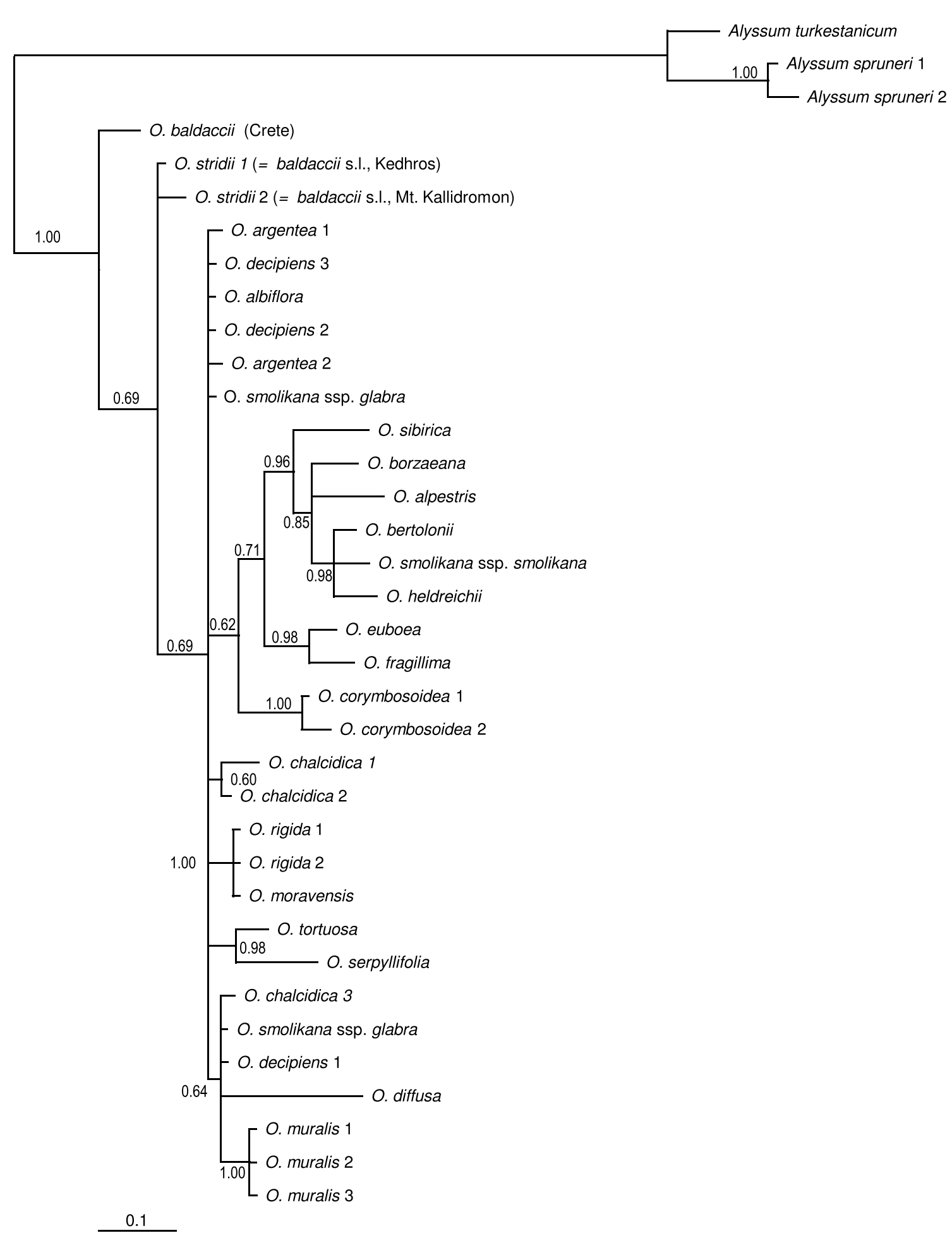

Fig. 6 Bayesian consensus phylogram from ITS-5.8S sequences of Odontarrhena, showing relationships of $O$. stridii and $O$. baldaccii s.s. to other taxa. Posterior Probability values are shown at the nodes 
Modhion e Kallidhromon", L. Cecchi \& F. Selvi 08.12, 6 Jun 2008 (FI-055055!; isotype ATH!) (Figs. 2a-c, 3a, c, e, 5a). -O. baldaccii auct. p.p. non (Vierh. ex Nyár.) Śpaniel, Phytotaxa 406: 251. 2019.

- O. fallacina auct. p.m.p. non (Hausskn.) Španiel, Al-Shehbaz, D.A.German \& Marhold, Pl. Syst. Evol. 301: 2485. 2015.

Latin diagnosis: Planta suffruticosa, caulis sterilibus numerosis, foliis strictis griseis, inflorescentia 1- (rare 2-) ramificata. Ab O. baldaccii differt habitu suffruticoso debiliore, ramiis sterilibus paucioribus; foliis linearibus-oblanceolatis (non oblanceolato-spathulatiis), minoribus sparsioribusque; foliis subtus trichomatis minoribus obtectis; siliculis in parte superiore quam in inferiore manifeste latioribus atque leviter S-configuratis in transversa sectione; ab O. heldreichii differt pedunculis erecto-patulis (non pendulis flexuosis), siliculis minoribus, deiscentibus, cum margine plano (non indeiscentibus cum margine sinuato); seminis fere non alatis.

English diagnosis: Suffruticose with several sterile shoots, narrow greyish leaves and 1- (rarely 2-) branched inflorescence. It differs from $O$. baldaccii by the less fruticose habit and less numerous sterile shoots from base, the smaller and sparser leaves, linear-oblanceolate in shape (rather than oblanceolate-spathulate), the smaller trichomes on lower leaf surface, the silicles widened in the upper half and slightly $\mathrm{S}$-shaped in cross section; it differs from $O$. heldreichii by the smaller dehiscent silicles without a thin undulate margin, borne on antrorsely arcuate pedicels and not pendent on a delicate, flexuous pedicel, and by the seeds almost without wing.

Etymology: This species is dedicated to Arne Strid, outstanding student of the Greek flora.

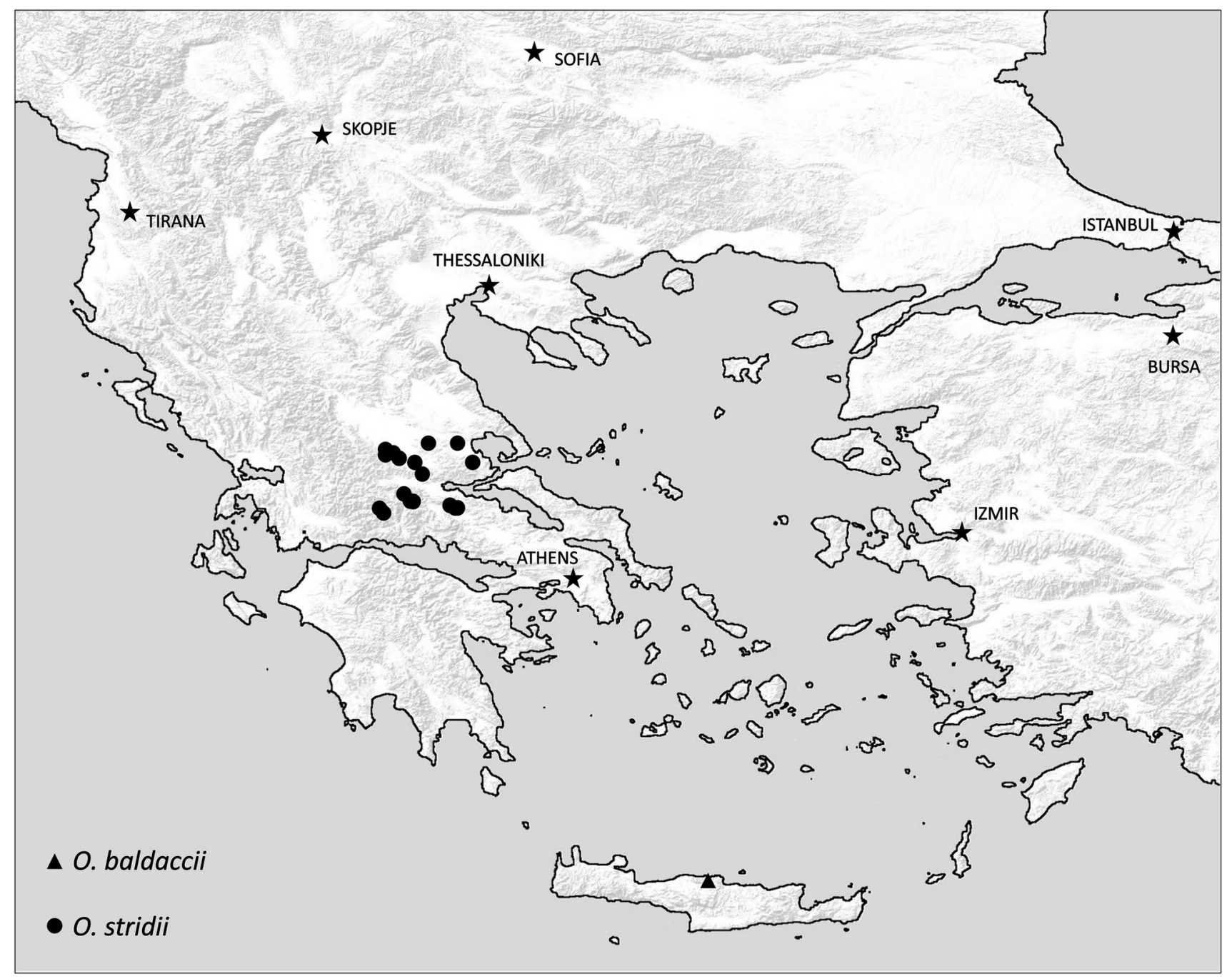

Fig. 7 Distribution of Odontarrhena baldaccii s.s. and $O$. stridii in Greece 
Description: Suffruticose perennial with thick taproot and sterile shoots from a woody base, $8-15 \mathrm{~cm}$ long, leafy, especially in the upper part. Basal leaves narrowly oblanceolate to almost linear in shape, (3)4-8(10) $\times 0.8-1.8 \mathrm{~mm}$, subacute at apex, greyish on both surfaces for dense sublepidote stellate hairs with 18-23 ray branches, $0.25-0.3 \mathrm{~mm}$ across; cauline leaves similar but sparser (or even absent) and often slightly larger, $8-12(15) \times 1.5-3 \mathrm{~mm}$. Fertile stems $15-35 \mathrm{~cm}$, often tinged with reddish, with stellate hairs similar to those on leaves but sparser; branches from the upper $1 / 3$ of the stem, ascending and forming a subcorymbose inflorescence, rarely the basal ones with secondary branches; racemes simple, $1-2.5 \mathrm{~cm}$ long, with 10-20 flowers; sepals ca. $1.5 \mathrm{~mm}$ long, petals ca. $3.2 \mathrm{~mm}$ long; short stamens with a simple appendage free to base; long stamens with a bidentate appendage, adnate to the filament on $2 / 3$ of its length. Silicle pedicels erect-patent, 4-7 mm long at maturity; silicles 3-4×2.3-2.7 mm; broadly ellipticobovate, slightly widened above half and S-shaped in cross section; valves slightly inflated on one side, with sparse stellate hairs $0.15 \mathrm{~mm}$ in diameter; style $0.8-1.2 \mathrm{~mm}$. Seeds $1.3-1.5 \times 1-1.2 \mathrm{~mm}$ long; wing very narrow to almost absent $(<0.15 \mathrm{~mm})$.

Distribution and habitat: This species is endemic to Sterea Ellas and Thessaly in central and southern continental Greece. We examined specimens from Nomos Fokidos (Mt. Iti), Nomos Fthiotidos (Mt. Kallidromo), Nomos Karditsis (Kedhros) and Nomos Magnisias (Kato Xenias); the distribution map is shown in Fig. 7 and selected voucher specimens with collection details are given in Appendix. Ecologically, $O$. stridii seems restricted to rocky or gravelly serpentine soils colonized by a sparse vegetation of xerophilous and often sclerophyllous shrubs, with serpentine-tolerant herbs and grasses. The altitudinal range is relatively wide, from 200 to ca. $1340 \mathrm{~m}$ a. s. 1 .

Apparently, there is no range overlap between $O$. stridii and $O$. heldreichii, the latter being found more to the north in Epiros and west Macedonia (Mt. Vourinos and Mt. Vermio) and at higher altitudes (up to over $2000 \mathrm{~m}$ a. s. 1.). On the other hand, the range of both species overlap with that of the widespread and polymorphic $O$. chalcidica that is often found on serpentine soils of mainland Greece from sea level to nearly $2000 \mathrm{~m}$ a. s. 1 .

\section{Key to Odontarrhena taxa in Greece}

1a. Dwarf, prostrate plants of high altitudes, with flowering stems $1-6 \mathrm{~cm}$ 2

1b. Taller plant, erect to ascendent; flowering stems $>$ $6 \mathrm{~cm}$ 3 2a. Mat-forming plant with many adventitious roots and very short, bud-like non-flowering shoots. Leaves 2-3 mm. Flowering stems $1-3 \mathrm{~cm}$. Inflorescence simple, condensed, with up to 10 flowers [Lefka Ori]

O. fragillima

2b. Non-mat-forming, taller plant. Leaves 4-8 $\mathrm{mm}$. Flowering stems $4-6 \mathrm{~cm}$. Inflorescence usually compound, with more than 10 flowers [Vardousia] O. nebrodensis subsp. tenuicaulis

3a. Inflorescence a simple raceme, or with 1-2 lateral, ascending branches O. euboea

3 b. Inflorescence subcorymbose with usually 5-10 lateral erecto-patent branches ................................. 4

4a. Style $0.2-0.5 \mathrm{~mm}$, not exceeding notch of silicles. Silicles indehiscent, pendent [Lesvos] O. lesbiaca

4b. Style (0.5)1-2 mm, exceeding notch of silicle. Silicles dehiscent or indehiscent ................................ 5

5 a. Seeds with a wing $0.3-1.3 \mathrm{~mm}$ broad. Stellate hairs on silicles mostly with 6-12(16) rays. Silicle valves flat or slightly inflated at centre .................................. 6

5 b. Seeds unwinged, rarely with a wing up to $0.3 \mathrm{~mm}$ broad. Stellate hairs on silicles mostly with 10-16(20) rays. Silicles valves flat or asymmetrically inflated ...................... 8

6a. Siliciles indehiscent with thin, distinctly undulate margin, pendent on a delicate, flexuous pedicel O. heldreichii

6b. Silicles dehiscent on patent or + antrorsely arcuate pedicels. Stellate hairs on leaves (0.3)0.5-1.2 mm across ..................................................... 7

7a. Silicles glaucous, margin \pm undulate, venation scarcely visible; stellate hairs on valves dense, $0.3-0.7 \mathrm{~mm}$ in diameter; cauline leaves acute ................... O. muralis (incl. Alyssum degenianum)

7b. Silicles usually pale green to yellowish green, usually with distinct venation; stellate hairs on valves sparse, $0.15-0.3 \mathrm{~mm}$ in diameter; cauline leaves obtuse

O. chalcidica

8a. Leaves widely spathulate to obovate-orbicular ......... 9

8 b. Leaves linear to narrowly oblanceolate-spathulate 11

9a. Basal leaves obtuse at apex, orbicular-spathulate to broadly obovate, less than $1 \mathrm{~cm}$ long, densely covered on both surfaces with dense, whitish pubescence (more than one layer of trichomes); silicles obovate (wider in the upper half), their valves sharply asymmetrically inflated and $\mathrm{S}$-shaped in cross section

O. sibirica

$9 \mathrm{~b}$. Basal leaves usually rounded at apex, variable in shape but usually more than $1 \mathrm{~cm}$ long, with upper surface green to greyish green, not covered with dense whitish pubescence (a single layer of trichomes); silicles 
elliptical to orbicular, with maximum width near the middle, their valves more or less symmetrically inflated, not asymmetrically inflated and S-shaped in cross section 10

10a. Flowering stems up to $30 \mathrm{~cm}$; inflorescence 2- to (rarely) 3-branched; silicles almond-shaped, 5-6(9) $\mathrm{mm}$ long, hairy; flowering from May to July, fruiting from June to August

O. smolikana

10b. Flowering stems up to 50(90) $\mathrm{cm}$; inflorescence 3- to (usually) 4-branched; silicles almond-shaped to broadly elliptic, sparsely hairy to glabrescent, $2.5-4 \mathrm{~mm}$ long; flowering from June to August, fruiting from August to October

O. decipiens

11a. Non-flowering shoots absent or few; silicles markedly S-shaped in cross section, broadly obovate to obcordate in outline, truncate to retuse, both valves strongly asymmetrically inflated

O. corymbosoides

11b. Non-flowering shoots numerous from base; silicles flat or valves slightly symmetrically or asymmetrically inflated; silicles not markedly S-shaped in cross section, elliptic (rarely obovate) in outline, attenuate at both ends 12

12a. Sepals 0.8-1(-1.5) mm. Petals $1.5-2 \mathrm{~mm}$. [Samos] O. samia

12b. Sepals (1.5-)2 mm. Petals (2.5-)3-4 mm .............. 13

13a. Lower leaves greenish above, greyish beneath, with stellate hairs $0.4-0.6 \mathrm{~mm}$ across, not conspicuously sublepidote. Silicle valves almost flat O. diffusa [Alyssum tenium]

13b. Lower leaves greyish on both surfaces, with conspicuously regular, sublepidote stellate hairs $0.2-0.4(0.5)$ $\mathrm{mm}$ across. Silicle valves slightly inflated

14a. Leaves of the basal sterile shoots 9-18 (20) $\times 2-4 \mathrm{~mm}$, spathulate, trichomes on lower leaf surface $0.3-0.4 \mathrm{~mm}$ across, silicles \pm elliptic or only slightly obovate, straight in cross....

O. baldaccii

14b. Leaves of the sterile shoots (3) $4-8(10) \times 0.8-1.8 \mathrm{~mm}$, linear-oblanceolate in shape, trichomes on lower leaf surface $0.2-0.3 \mathrm{~mm}$ across; silicles widened in the upper half and slightly S-shaped in cross section O. stridii sp. nov.

Acknowledgements Authors wish to thank Arne Strid for sharing opinions and providing information on Odontarrhena in Greece. Isabella Bettarini provided valuable help during fieldwork and preparation of samples. The Curators of the herbaria mentioned in the Material and Method sections kindly allowed the study of their collections. Laura Vivona assisted with the preparation of figures. This research was supported by funds from Agronickel to C.G. and F.S., a FACCE SURPLUS project supported by H2020 ERA-NET Cofund, and from the Czech Science Foundation (Grant No. 19-06632S) to S.S.

\section{Compliance with ethical standards}

Conflict of interest The authors declare that they have no conflict of interest.

\section{Appendix}

List of examined specimens (paratypes) of Odontarrhena stridii L.Cecchi, Španiel \& Selvi from Greece.

[Central Greece], prov. Fthiotis, Iti-Massiv, Umgebung von Neochorion, 1400 m. ü. M., felsdurchragte Bergweiden, reich an Astragalus und Eryngium. (...) Atlas Fl. Eur.: FH 1", 20 Jun 1982, I. Hagemann, H. Scholz and W. Schwerz, 227 (B!) • [Central Greece] "Nom. Fthiotidhos, Ep. Lokridhos: Mt. Kallidromon, $11 \mathrm{~km}$ NE-ENE of Amfiklia. Serpentine mountain called Palioanlias E of the road btw. The villages Modhion and Kallidromon. Rocky slopes with macchie and scattered Pinus halepensis, 600900 m.", 28 Aug 1982, P. Hartvig, R. Franzén and K. I. Christensen 10519 (B!) • [Central Greece] "Nom.Fokis, Ep.Parnassidhos, 1,8 km SO Pira (...) Wacholderhänge m.sehr trocknen Wiesen u.Schuttreißen/UTM $38^{\circ} 44^{\prime} \mathrm{N}$, $22^{\circ} 17^{\prime}$ E FH 1188 (...) 1140 m”, 30 May 1988, E. Willing 5336a, 5336b (B!) • [Central Greece] "Nom.Fokis, Ep.Lokridhos, Kallidhromos, 4,0 km SO Kallidhromo (Fth 62 d) (...9, Iti, oberhalb Pira (Fth 66) (...) $38^{\circ} 41^{\prime} 30^{\prime \prime} \mathrm{N}$, $22^{\circ} 41^{\prime} \mathrm{E} / \mathrm{Felsanriß}$ unter Hartlaubgebüsch.Ser/UTM FH 48 (...) 1230 m", 9 Jun 1991, E. Willing 14.955 (B!) • [Central Greece] "Nom.Fokis, Ep.Fthiotidhos, Iti, oberhalb Pira (Fth 66) (...)Wiesen m.Tannen u.Juniperus $/ 38^{\circ} 44^{\prime} 30^{\prime \prime} \mathrm{N}$, $22^{\circ} 16^{\prime}$ E/UTM FH 19 (...) 1230 m”, 11 Jun 1991, E. Willing 15.214 (B!) • [Central Greece] "Nom.Fokis, Ep.Dhoridhos, $3.1 \mathrm{~km}$ SSW Artotina (Fok 82 b) (...) Felsige Hangböschung unter Tannenwald, Sa/38 $40^{\prime} 30^{\prime \prime} \mathrm{N}, 22^{\circ} 0^{\prime} 30^{\prime \prime} \mathrm{E} / \mathrm{UTM}$ EH 8881 (...) 1340 m”, 17 Jun 1991, E. Willing 15.923 (B!) - [Central Greece] "Nom.Magnisia, Ep.Almirou, 1,9 km NO Porta-Gipfel (Mag 18 c) (...) Q.coccifera- Gebüsch, magere Krautfluren $/ 39^{\circ} 15^{\prime} \mathrm{N}, 22^{\circ} 41^{\prime} \mathrm{E} / \mathrm{UTM}$ FJ 4546 (...) 230 m", 6 May 1993, E. Willing 24.169 (B!) • [Central Greece] "Nom.Magnisia, Ep.Almirou, Moni Xenias (Mag 19 b) (...) Trockene Serpentinhänge unter Q.cocciferaGebüsch $/ 39^{\circ} 5^{\prime} \mathrm{N}, 22^{\circ} 49^{\prime} \mathrm{E} / \mathrm{UTM}$ FJ 5828 (...) 270-300 m”, 11 May 1993, E. Willing 25.115 (B!) • [Tessaglia] "Nom. and Ep. Kardhitsa: $\mathrm{S}$ of Khedros along road to Loutra Smokovou, alt. 240(-350) m, 39 $11(-12.5)^{\prime} \mathrm{N}, 2^{\circ} 02^{\prime} 20^{\prime \prime} \mathrm{E}$. Rocky slopes and scree, serpentine", 12 Jun 1995, W. Greuter and B. Zimmer, Greuter Pl. Graec. 24417 (B!) • [Central Greece] "Fokis, Ep. Dhoridhos/3,7 km SSW Artotina (Fok 
121) (...) Tannenwald, feuchte Rinne, $1340 \mathrm{~m} / \mathrm{EH} 88.80$, $38^{\circ} 40^{\prime} 00^{\prime \prime} \mathrm{N}, 22^{\circ} 1^{\prime} 00^{\prime \prime} \mathrm{E} ", 29$ Jun 1996, R. Eisenblätter and E. Willing 45.291a (B!) • [Central Greece] "Fokis, Ep. Dhoridhos $/ 5,8$ km SSW Artotina (Fok 120) (...) Krautfluren, Tannenwald, $1480 \mathrm{~m} / \mathrm{EH} 87.88,38^{\circ} 38^{\prime} 30^{\prime \prime} \mathrm{N}, 22^{\circ} 1^{\prime} 00^{\prime \prime} \mathrm{E} "$, 29 Jun 1996, R. Eisenblätter and E. Willing 45.909 (B!) • [Central Greece] "Fthiotida, regione di Lamìa, al p.so di Fourka presso Domokos, $1000 \mathrm{~m}$, mescolanza di calcare e serpentino", 2 May 2001, M. Bigazzi. and F. Selvi s.n (FI 055058!) • [Central Greece] "Karditsa, SO Anavra (...) Krautfluren in Laubgebüsch, 350 m/Kar 207 a, EJ 93.55.14, $39^{\circ} 09^{\prime} 45^{\prime \prime} \mathrm{N}, 22^{\circ} 06^{\prime} 04^{\prime \prime} \mathrm{E} ", 28$ May 2007, R. Willing and E. Willing 162.236 (B!) • [Central Greece] "Karditsa, SO Loutra Kaitsis (...) Felsfluren, Schuttfluren, 400 m/Kar 208, FJ 03.01.39, 39 $07^{\prime} 52^{\prime \prime} \mathrm{N}, 22^{\circ} 09^{\prime} 37^{\prime \prime} \mathrm{E} ", 28$ May 2007, $R$. Willing and E. Willing 162.293 (B!) • [Thessaly] "Larisa, SO Achillion (...) Q.coccifera- Gebüsch, trockene Krautfluren, $300 \mathrm{~m} / \mathrm{Lar} 201$, FJ 24.36.63, 39 ${ }^{\circ} 15^{\prime} 27^{\prime \prime} \mathrm{N}, 22^{\circ} 25^{\prime} 57^{\prime \prime} \mathrm{E} "$, 22 Mar 2008, R. Willing and E. Willing 174.013 (B!) • [Central Greece] "Fthiotis, SO Domokos (...) Felsige Krautfluren, Quelle, 495 m/Fth 412, FJ 12.37.11, 39 $05^{\prime} 09^{\prime \prime} \mathrm{N}$, $22^{\circ} 18^{\prime 2} 28^{\prime \prime E} ", 24 / 04 / 2008, R$. Willing and E. Willing 174.893, B! • [Thessaly] "Trikala, Khedros, ofioliti lungo la strada per Loutropigi, $180 \mathrm{~m}, 39^{\circ} 11.777^{\prime} \mathrm{N}, 22^{\circ} 02.052^{\prime} \mathrm{E}$ ", 5 Jun 2008 , L. Cecchi and F. Selvi s.n. (FI 055056!, FI055057!) • [Thessaly] "Karditsa, oltre Kedros verso Loutropigi, pendii rocciosi di serpentino lungo la strada nella valle del torrente, $39^{\circ} 10.028^{\prime} \mathrm{N}, 22^{\circ} 02.587^{\prime} \mathrm{E}, 270 \mathrm{~m}$. Serpentino”, 8 Aug 2018, F. Selvi and I. Bettarini s.n. ( FI 055800!) • [Thessaly] "Magnissia, Almiros, presso il monastero di Kato Xenia (Moni Xenia), rocce e brecce nelle radure di boscaglia aperta di Quercus coccifera, suolo serpentinoso, $39^{\circ} 05.474^{\prime} \mathrm{N}$, $22^{\circ} 49.701^{\prime} \mathrm{E}$, ca. 240 m”, 31 May 2019, F. Selvi and I. Bettarini s.n. (FI 056356!)

\section{Information on Electronic Supplementary Materi- als}

Online Resource 1. Table of character values measured on 10 specimens of Odontarrhena baldaccii s.s. from Crete (Cr1-Cr10) and 15 specimens of $O$. baldaccii s.l. (=O. baldaccii s.l.) from three mainland populations (five each; Ke: Kedhros; Ka: Mt. Kallidromo; KX: Kato Xenia).

Online Resource 2. List of taxa and accessions included in the phylogenetic analysis, with origin, voucher (herbarium acronyms are according to Index Herbariorum) and GenBank accession numbers.

Online Resource 3. Chromosome metaphase plates of Odontarrhena baldaccii s.s. from Crete, $2 n=16$ (a), O. stridii (=baldaccii s.1.) from Kedhros, Thessaly, $2 n=16$ (b), O. heldreichii from Katara Pass, north Pindus, $2 n=16(\mathbf{c}), O$. chalcidica from Malakasi, north Pindus, $2 n=32(\mathbf{d})$.

Online Resource 4. Alignment of ITS-5.8S sequences used for the phylogenetic analysis.

\section{References}

Ball PW, Dudley TR (1993) Alyssum L. In: Tutin TG, Heywood VH, Burges NA, Moore DM, Valentine DH, Walters SM, Webb DA (eds) Flora Europaea, vol. 1, 2nd edn. Cambridge University Press, Cambridge, pp 359-369

Bani A, Echevarria G, Mullaj A, Reeves RD, Morel JL, Sulçe S (2009) Ni hyperaccumulation by Brassicaceae in serpentine soils of Albania and NW Greece. Northeast Nat 16:385-404

Bettarini I, Colzi I, Coppi A, Cecchi L, Falsini S, Echevarria G, Pazzagli L, Selvi F, Gonnelli C (2019) Unravelling soil and plant metal relationships in Albanian Ni-hyperaccumulators of genus Odontarrhena (syn. Alyssum sect. Odontarrhena, Brassicaceae). Pl Soil 440:135-149. https://doi.org/10.1007/s11104-019-04077-y

Borchsenius F (2009) FastGap 1.2. Department of Biosciences, Aarhus University, Denmark. Available at: http://www.aubot.dk/FastG ap_home.htm

Brooks RR, Radford CC (1978) Nickel accumulation by European species of the genus Alyssum. Proc Roy Soc London B 200:217-224

Cecchi L, Gabbrielli R, Arnetoli M, Gonnelli C, Hasko A, Selvi F (2010) Evolutionary lineages of nickel hyperaccumulation and systematics in European Alysseae (Brassicaceae): evidence from nrDNA sequence data. Ann Bot (London) 106:751-767. https:// doi.org/10.1093/aob/mcq162

Cecchi L, Colzi I, Coppi A, Gonnelli C, Selvi F (2013) Diversity and biogeography of Ni-hyperaccumulators of Alyssum section Odontarrhena (Brassicaceae) in the Central Western Mediterranean: evidence from karyology, morphology and DNA sequence data. Bot J Linn Soc 173:269-289. https://doi.org/10.1111/boj.12084

Cecchi L, Bettarini I, Colzi I, Coppi A, Echevarria G, Pazzagli L, Bani A, Gonnelli C, Selvi F (2018) The genus Odontarrhena (Brassicaceae) in Albania: taxonomy and nickel accumulation in a critical group of metallophytes from a major serpentine hot-spot. Phytotaxa 351:1-28. https://doi.org/10.11646/phytotaxa.351.1.1

Contandriopoulos J (1970) Contribution à l'étude cytotaxinomique des Alysseae Adams de Grèce. Ber Schweiz Bot Ges 79:313-334

Coppi A, Lastrucci L, Ferretti G, Viciani D (2018) A phylogenetic study of two recently described endemic species of the Saxifraga granulata group from the central-north Mediterranean region (Italy) and their position in the context of the series Saxifraga (Saxifragaceae). Syst Biodivers 16:784-790. https://doi. org/10.1080/14772000.2018.1492997

De Montmollin B (1984) Etude cytotaxonomique de la flore de la Crète. II. Nombres chromosomiques. Bot Helv 94:261-267

Dimopoulos P, Raus T, Strid A (2018) "Flora of Greece" Web, version 2. Available at: http://portal.cybertaxonomy.org/flora-greec e/cdm_dataportal/taxon/8b89251c-a8ca-4ac7-a055-bd97fd0232 01. Accessed 10 Apr 2020

Doyle JJ, Doyle JL (1990) Isolation of plant DNA from fresh tissue. Focus 12:13-15

Dyer AF (1979) Investigating chromosomes. Edward Arnold, London

Favarger C, Contandriopoulos J (1961) Essai sur l'endemisme. Ber Schweiz Bot Ges 71:384-408

Fielding J, Turland N (2005) Flowers of crete. Royal Botanic Gardens, Kew

Hammer Ø, Harper DAT, Ryan PD (2001) PAST: Paleontological statistics software package for education and data analysis. Palaeontol Electronica 4(1):1-9

Hartvig P (2002) Alyssum. In: Strid A, Tan K (eds) Flora Hellenica, vol. 2. ARG Gantner Verlag Ruggell, Koenigstein, pp 199-227 
Jalas J, Suominen J (1996) Atlas Florae Europeae, vol. 11. The Committee for Mapping the Flora of Europe and Societas Biologica Fennica Vanamo, Krämer, Helsinki

Katoh K, Standley DM (2013) MAFFT multiple sequence alignment software version 7: improvements in performance and usability. Molec Biol Evol 30:772-780. https://doi.org/10.1093/molbev/ mst010

Kidd PS, Bani A, Benizri E, Gonnelli C, Hazotte C, Kisser J, Konstantinou M, Kuppens T, Kyrkas D, Laubie B, Malina E, Morel JL, Olcay H, Pardo T, Pons MN, Prieto-Fernández Á, Puschenreiter M, Quintela Sabaris C, Ridard C, Rodríguez-Garrido B, Rosenkranz T, Rozpądek P, Saad R, Selvi F, Simonnot MO, Tognacchini A, Turnau K, Ważny R, Witters N, Echevarria G (2018) Developing sustainable agromining systems in agricultural ultramafic soils for nickel recovery. Frontiers Environm Sci 6:44. https://doi. org/10.3389/fenvs. 2018.00044

Ledebour CF (1830) Icones plantarum novarum vel imperfecte cognitarum floram rossicam, imprimis altaicam, illustrantes. Centuria II. I. Deubner, Rigae [Riga] \& Treuttel et Würtz, Londini, Parisiis et Argentorati [London, Paris and Strasbourg] \& Libraria Parisiensi, Bruxellae [Brussels]. https://doi.org/10.5962/bhl.title.46626

Li Y, Feng Y, Lv G, Liu B, Qi A (2015) The phylogeny of Alyssum (Brassicaceae) inferred from molecular data. Nordic J Bot 33:715-721. https://doi.org/10.1111/njb.00588

Marhold K (2011) Brassicaceae. In: Euro+Med Plantbase - the information resource for Euro-Mediterranean plant diversity. Available at: http://ww2.bgbm.org/EuroPlusMed/PTaxonDetail.asp?NameC ache $=$ Alyssum $\&$ PTRefFk $=7200000$

Melichárková A, Španiel S, Marhold K, Hurdu B-I, Drescher A, Zozomová-Lihová J (2019) Diversification and independent polyploid origins in the disjunct species Alyssum repens from the SE Alps and the Carpathians. Amer J Bot 106:1499-1518. https://doi. org/10.1002/ajb2.1370

Morrison RR, Brooks RR, Reeves RD (1980) Nickel uptake by Alyssum species. Pl Sci Lett 17:451-457

Nyárády EJ (1928) [“1927"]. Studiu preliminar asupra unor specii de Alyssum din sectia Odontarrhena. Vorstudium über einige Arten der Section Odontarrhena der Gattung Alyssum. Bul Grăd Bot Univ Cluj 7(1-4):3-160

Nyárády EJ (1929a) ["1928"]. Studiu preliminar asupra unor specii de Alyssum din secţia Odontarrhena. Vorstudium über einige Arten der Section Odontarrhena der Gattung Alyssum (Forsetzung). Bul Grăd Bot Univ Cluj 8(2-4):152-156

Nyárády EJ (1929b) Studiu preliminar asupra unor specii de Alyssum din secţia Odontarrhena. Vorstudium über einige Arten der Section Odontarrhena der Gattung Alyssum (Schluss). Bul Grăd Bot Univ Cluj 9(1-2):1-68

Nyárády EJ (1930) Neue Beiträge zur Kenntnis der Balkanischen Alyssum-Arten. Rep Spec Nov Reg Veg 27:392-395

Nyárády EJ (1932) [“1931"] Les formes vraies et fausses de l'espèce Alyssum alpestre L. Bul Grăd. Bot Univ Cluj 9(3-4):69-78

Nyárády EJ (1939) ["1938"]. Neue Alyssum Arten und Formen aus der Odontarrhena-Sektion. Bul Grăd Bot Univ Cluj 18(1-4):82-99

Nyárády EJ (1949) Synopsis specierum, variationum et formatum sectionis Odontarrhenae generis Alyssum. Analele Acad Republ Populare Române Sect Geol Geogr Biol Ser A 1:1-133

Phitos D, Constantinidis T, Kamari G (2009) The red data book of rare and threatened plants of Greece, vols I-II, Helliniki Votaniki Eteria, Patras (in Greek)

Posada D, Crandall KA (1998) ModelTest: testing the model of DNA substitution. Bioinformatics 14:817-818

Reeves RD, Baker AJM, Tanguy J, Erskine PD, Echevarria E, van der Ent A (2018) A global database for plants that hyperaccumulate metal and metalloid trace elements. New Phytologist 218:407411. https://doi.org/10.1111/nph.14907
Rešetnik I, Satovic Z, Schneeweiss GM, Liber Z (2013) Phylogenetic relationships in Brassicaceae tribe Alysseae inferred from nuclear ribosomal and chloroplast DNA sequence data. Molec Phylogen Evol 69:772-786. https://doi.org/10.1016/j.ympev.2013.06.026

Ronquist F, Huelsenbeck LP (2003) MrBayes 3: bayesian phylogenetic inference under mixed models. Bioinformatics 19:1572-1574. https://doi.org/10.1093/bioinformatics/btg180

Salmerón-Sánchez E, Fuertes-Aguilar J, Španiel S, Pérez-García FJ, Merlo E, Garrido-Becerra JA, Mota J (2018) Plant evolution in alkaline magnesium-rich soils: a phylogenetic study of the Mediterranean genus Hormathophylla (Cruciferae: Alysseae) based on nuclear and plastid sequences. PLoS ONE 13:e0208307. https:// doi.org/10.1371/journal.pone.0208307

Selvi F, Sutorý K (2012) A synopsis of the genus Cynoglossum (Boraginaceae-Cynoglosseae) in Italy. Pl Biosyst 146:461-479. https ://doi.org/10.1080/11263504.2012.667842

Selvi F, Carrari E, Colzi I, Coppi A, Gonnelli C (2017) Responses of serpentine plants to pine invasion: vegetation diversity and nickel accumulation in species with contrasting adaptive strategies. Sci Total Environm 595:72-80. https://doi.org/10.1016/j. scitotenv.2017.03.249

Simmons MP, Ochoterena H (2000) Gaps as characters in sequencebased phylogenetic analyses. Syst Biol 49:369-381. https://doi. org/10.1093/sysbio/49.2.369

Španiel S (2019) Two new combinations and a new synonym in the genus Odontarrhena (Brassicaceae). Phytotaxa 406:250-254. https://doi.org/10.11646/phytotaxa.406.4.4

Španiel S, Kempa M, Salmerón-Sánchez E, Fuertes-Aguilar J, Francisco Mota J, Al-Shehbaz IA, German DA, Olšavská K, Šingliarová B, Zozomová-Lihová et al (2015) AlyBase—database of names, chromosome numbers, and ploidy levels of Alysseae (Brassicaceae), with a new generic concept of the tribe. Pl Syst Evol 301:2463-2491. https://doi.org/10.1007/s00606-015-1257-3

Španiel S, Marhold K, Zozomová-Lihová J (2017) The polyploid Alyssum montanum-A. repens complex in the Balkans: a hotspot of species and genetic diversity. Pl Syst Evol 303:1443-1465. https ://doi.org/10.1007/s00606-017-1470-3

Stefanović V, Tan K, Iatrou G (2003) Distribution of the endemic Balkan flora on serpentine I.-Obligate serpentine endemics. Pl Syst Evol 242:149-170. https://doi.org/10.1007/s00606-003-0044-8

Strid A (1983) In IOPB chromosome number reports LXXVIII. Taxon 32:138-140

Strid A (2016) Atlas of the Aegean Flora, part 1: 150; part 2: 217. Englera 33, Botanic Garden and Botanical Museum, Berlin

Tumi AF, Mihailović N, Gajić BA, Niketić M, Tomović G (2012) Comparative Study of Hyperaccumulation of nickel by Alyssum murale. Populations from the Ultramafics of Serbia. Polish J Environm Stud 21:1855-1866

Vierhapper F, Rechinger KH (1935) Bearbeitung der von Ignaz Dorfler in Jahre 1904 auf Kreta gesammelten Blüten- and Farnpflanzen. Österr Bot Z 84:123-157

Warwick SI, Sauder CA, Al-Shehbaz IA (2008) Phylogenetic relationships in the tribe Alysseae (Brassicaceae) based on nuclear ribosomal ITS DNA sequences. Botany 86:315-336. https://doi. org/10.1139/B08-013

Zozomová-Lihová J, Marhold K, Španiel S (2014) Taxonomy and evolutionary history of Alyssum montanum (Brassicaceae) and related taxa in southwestern Europe and Morocco: diversification driven by polyploidy, geographic and ecological isolation. Taxon 63:562-591. https://doi.org/10.12705/633.18

Publisher's Note Springer Nature remains neutral with regard to jurisdictional claims in published maps and institutional affiliations. 